\title{
Fast Pyrolysis Biochar Flammability Behavior for Handling and Storage
}

\author{
Bernardo del Campo', Thomas Brumm²*, and Nir Keren ${ }^{3}$ \\ 'ARTi - Advanced Renewable Technology International: Prairie City, lowa, US \\ ${ }^{2}$ Professor, Department of Agricultural and Biosystems Engineering, lowa State University, Ames, \\ lowa, USA. \\ ${ }^{3}$ Associate Professor, Department of Agricultural and Biosystems Engineering, lowa State \\ University, Ames, lowa, USA. \\ Autor para correspondencia/Corresponding author: tbrumm@iastate.edu
}

\section{Comportamiento de inflamabilidad de biocarbón de pirólisis rápida para transporte y almacenamiento}

\begin{abstract}
Biochar is a fairly new material in the research arena with limited information on safety aspects related to transportation, storage, disposal or field application methods. The objective of this research was to assess the flammability characteristics of fast pyrolysis biochars with test methods EPA 1030 and ASTM D4982. Results indicated that biochar is a non-flammable substance when tested with EPA 1030 Ignitability of Solids. However, when tested with ASTM D4982, a fast screening method, biochars showed potential risks of flammability. Nevertheless, the addition of $20-50 \%$ of moisture reduced any flammability concern.
\end{abstract}

Fast pyrolysis biochar was more prone to flammability than traditional charcoal and slow pyrolysis biochar tested in this study. Still, fast pyrolysis biochars presented lower flammability potential (ASTM D4982) in comparison to its precursor biomass. The flammability propagation measured with EPA 1030 had high correlations with oxygen content and surface area of the fast pyrolysis biochar. The combustion reaction of fast pyrolysis biochar is a flameless combustion process, with a slow burning rate, and most commonly exhibiting a hot ember smoldering propagation front.

This paper illustrates the necessity of performing recurring tests due to biochar's intrinsic Editado por / Edited by: Juan Sebastián Proaño Recibido / Received: 05/24/2021

Aceptado / Accepted: 09/14/2021

Keywords: Fast Pyrolysis Biochar, flame propagation, ignitability, safety

\section{Resumen}

El biocarbón es un material relativamente nuevo en el campo de la investigación con información limitada sobre los aspectos de seguridad relacionados con el transporte, el almacenamiento, o los métodos de aplicación en el campo. El objetivo de esta investigación fue evaluar las características de inflamabilidad de biocarbón de pirólisis rápida con los métodos de prueba EPA 1030 y ASTM D4982. Los resultados indicaron 
que el biocarbón es una sustancia no inflamable cuando se prueba con la inflamabilidad de sólidos EPA 1030. Sin embargo, cuando se probó con ASTM D4982, un método de detección rápido, los biocarbones mostraron riesgos potenciales de inflamabilidad. Sin embargo, la adición de un 20-50\% de humedad redujo el riesgo de inflamabilidad.

El biocarbón de pirólisis rápida era más propenso a ser inflamable que el carbón vegetal tradicional y el biocarbón de pirólisis lenta probado en este estudio. Aún así, los biocarbones de pirólisis rápida presentaron un potencial de inflamabilidad menor (ASTM D4982) en comparación con su biomasa precursora. La propagación de la inflamabilidad medida con EPA 1030, tuvo altas correlaciones con el contenido de oxígeno y el área de superficie del biocarbón de pirólisis rápida. La reacción de combustión del biocarbón de pirólisis rápida es un proceso de combustión sin llama, con una velocidad de combustión lenta y, por lo general, exhibe un frente de propagación de brasa ardiente. Este documento ilustra la necesidad de realizar pruebas recurrentes debido a la variabilidad intrínseca del biocarbón derivada de los diferentes modos de producción y materia prima utilizada.

Palabras clave: Biocarbón de pirólisis rápida, propagación de llama, inflamabilidad, seguridad

\section{INTRODUCTION}

Biochar, as defined by the International Biochar Initiative (IBI), is "a solid material obtained from the thermochemical conversion of biomass in an oxygen-limited environment" [1]. More simply, biochar is a charcoal-like material that can be used for soil amendment to improve plant growth, soil quality and sequester carbon dioxide [2, 3]. Biochar has been a hot topic in the literature due to its increased water adsorption capacity, pH buffer potential, and cation and anion exchange capacity. These characteristics are determined by the specific feedstock and production conditions. As opposed to other soil amendments, such as compost or worm casts, biochar has a high concentration of recalcitrant carbon due to its intrinsic aromatic carbon ring structure [4]. Therefore, biochar can be a unique alternative to combating greenhouse-gas emissions and improving degraded soils [4].

Physical and chemical characteristics of biochar can vary widely $[5,6]$. There are various thermochemical methods to produce biochar (pyrolysis, carbonization, gasification, hydrothermal liquefaction, etc.), including different feedstocks (grasses, wood, waste materials, algae, etc.) and processing conditions (temperatures from $300-1000^{\circ} \mathrm{C}$, vacuum to high pressures, in nitrogen gas to superheated steam, etc.). Therefore, the resulting biochars may have similar appearances but have very different chemical and physical characteristics $[2,6,7]$. Just to name a few variances among biochars, carbon content can range from $30-90 \%$ d.b. [8], the $\mathrm{pH}$ from $4-12$ (although its $\mathrm{pH}$ is typically basic) [8], the cation exchange capacity from $5-90 \mathrm{cmolc} / \mathrm{kg}$ [8], and the microporosity measurements by Brunauer-Emmett-Teller BET surface area from 1 to $1000 \mathrm{~m}^{2} / \mathrm{g}$ [9].

For the purpose of this study, it is important to consider not just the carbon constituent itself but also contaminants that can be brought in during harvesting, the production 
Artículo/Article en ciencias e

of the biomass feedstock, or the thermochemical process which could influence flammability characteristics. Most typical contaminants are dirt and soil acquired from the biomass harvesting process and raking; sand used in entrained flow or fluidized reactors used to enhance heat transfer; and re-condensed bio-oil vapors responsible for a small percentage of the volatile content in the fast pyrolysis biochar (Figure 1).

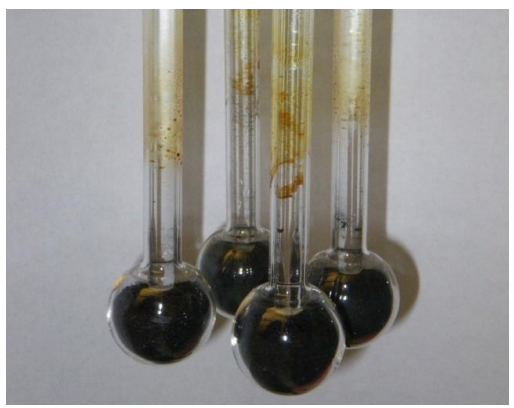

$1 \mathrm{~A}[21]$

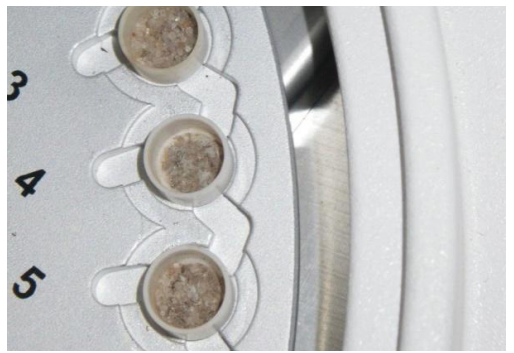

1B

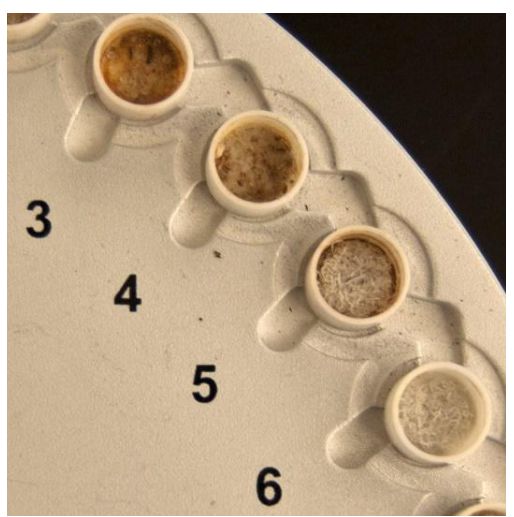

$1 C$

Figure 1. Bio-oil condensation, sand contamination, and oil contamination in various biochars (from top to bottom) 
Bio-oil that re-condenses in the biochar is known to have a higher propensity to ignite as well as lower flash points than biochar. Re-condensed bio-oil can potentially trigger oxidation reactions at lower temperatures. For example, when analyzing biochar's surface area, slow pyrolysis biochars degassed at the same conditions had no tar formation as opposed to fast pyrolysis char. Figure 1 shows tar condensation on wall vials containing fast pyrolysis biochars during $300^{\circ} \mathrm{C}$ degassing for surface area analysis (top), sand contamination in fast pyrolysis biochar produced in a fluidized bed (middle), and ashes from biomass without soil contamination or clean harvest 5-6, and contamination with soil 3-4 (bottom).

Sand particles from the fast pyrolysis fluidized bed reactor are visible in the red oak biochar ash samples after they have undergone proximate analysis (Figure 1, middle picture). This indicates that sand from the bed is elutriating out of the reactor, most likely due to the small freeboard region of the reactor (between the bed and outlet plumbing going towards the cyclones) being too short or fluidization properties not optimized for the sand and gas flow rates being used. The presence of foreign sand in the biochar sample resulted in high "ash" contents, which may have a different flammability potential. Another important source of contamination is the soil, especially for crops where soil particles that could be raked and harvested with the biomass feedstock.

The high heating value of the biochar is an important parameter for understanding the energy that will be produced once it has been oxidized or has undergone combustion reactions. However, the energy content itself does not determine the rate at which that energy and reaction products are formed nor the conditions at which the reactions will be triggered. For example, the energy content in graphite is higher than typical biochars (approximately $32 \mathrm{MJ} / \mathrm{kg}$ vs. $\sim 20 \mathrm{MJ} / \mathrm{kg}$ ), but due to the carbon crystalline structure and chemical stability at standard conditions, graphite is very difficult to ignite $[10,11]$. It is important to note that the energy content discussed is with respect to a dry base, and thus moisture that is typically present in biochar materials has to be removed before combustion can occur. This moisture deters much of the flammability concerns.

There are several classifications for flammable solids. The United Nations' classification of flammable solid is defined as "a solid which is readily combustible, or which may cause or contribute to fire through friction." Readily combustible solids are considered "powder, granular or pasty chemicals, which are dangerous if they can be easily ignited by brief contact with an ignition source such as a burning match and if the flame spreads rapidly" $[12,13]$. The important consideration here is that the substance can be ignited when exposed to flames or friction and that has rapid flame propagation.

The US Department of Transportation (US DoT) divides substances into nine classes of hazardous materials (Hazmats). Class 4 addresses flammable hazardous materials. Under Class 4, there are three different types of flammable classes: 4.1 flammable solids; 4.2 spontaneously combustible materials; and 4.3 solids that are hazardous when wet.

- Class 4.1 are flammable solids, self-reactive substances, and desensitized explosives. This class refers to materials that are self-reactive with accelerated decomposition and are potentially explosive when confined. 
- Class 4.2 are pyrophoric substances and self-heating substances that spontaneously combust. This class identifies spontaneously combustible materials, and tests are performed to determine if the material in a $25 \mathrm{~mm}$ or $100 \mathrm{~mm}$ sample mesh cube at 100,120 , and $140{ }^{\circ} \mathrm{C}$ will undergo self-heating and potential smoldering or combustion.

- Class 4.3 are materials that are hazardous when wet. When exposed to various degrees of moisture, these materials can heat and emit gasses and thus present safety concerns (if producing more than $1 \mathrm{~L}$ of gas per $\mathrm{kg}$ of material).

Zhao et al. [11] conducted a study of 34 biochars. None of these biochars were identified as flammable, and no significant burning or smoldering propagation was noted either, according to the UN flammability methodology. When comparing different thermochemical production methods, these researchers found that fast pyrolysis was more likely to be flammable, followed by slow pyrolysis and then gasification chars (which had no smoldering propagation).

Zhao et al. [11] also reported that there was a higher propagation of fast pyrolysis material (but not enough to be considered flammable). This higher propagation correlated negatively with fixed carbon and positively correlated with volatile content. The hydrogen to carbon ratio $(\mathrm{H}: \mathrm{C})$ was also positively correlated with the tendency to show flammability characteristics and potentially indicating that more stringent pyrolysis conditions (lower $\mathrm{H}: \mathrm{C}$ ) will result in less flammable materials (higher aromaticity structure). Also, the propensity for flammability of fresh biochars was higher for those made at $450{ }^{\circ} \mathrm{C}$ than at $350^{\circ} \mathrm{C}$ (very low-temperature char or more appropriately identified as torrified material). Cote [15], however, reported that the carbonization of wood at low temperatures leaves the charcoal with chemically unstable conditions, opposing Zhao's results.

Fast pyrolysis biochar is a fairly new material to researchers [16], and many questions are yet to be answered regarding the hazardousness of this material. Further studies will be needed to thoroughly understand which types of hazards biochar can pose. What methodologies can be used to effectively assess the potential hazards? What conditions should be avoided in order to minimize the risks of a safety incident? How is flammability affected by the production process, and how does it vary due to product characteristics? How do thermochemical processes, feedstocks, particle size, quenching mechanisms, and impurities affect flammability?

The objective of this study is to evaluate flammability characteristics of fast pyrolysis biochar with EPA test method 1030 for Ignitability of Solids [17] and ASTM D4982 for flammability potential screening [18], and to compare the results with current information for carbonaceous materials. The results could provide valuable information for handling biochar and for communicating biochar flammability data. 


\section{EXPERIMENTAL}

\section{Biochar and reactor types}

Several fast pyrolysis biochars were produced from agricultural and forestry feedstock (e.g., red oak, corn stover, loblolly pine, switchgrass) in a wide range of operating conditions. Different reactors, biomass feedstocks, and processing parameters resulted in fast pyrolysis biochars with a wide range of chemical composition (see Table 1 and Table 2). The three types of reactors used in this study are fluidized bed, free fall, and auger reactor (Figure 2). Temperatures ranged from 400 to $600^{\circ} \mathrm{C}$ with a residence time between 2 and 10 seconds for the fluidized bed, less than five seconds for the free fall, and between 20 and 60 seconds with the auger reactor. Detailed descriptions of different types of pyrolysis reactors were described by Brown [19].

Table 1. Chemical properties of fast pyrolysis biochar used for flammability and self-reactivity assessment

\begin{tabular}{|c|c|c|c|c|c|c|c|c|c|c|c|c|c|}
\hline $\begin{array}{l}\text { Biomass } \\
\text { feedstock }\end{array}$ & $\begin{array}{c}\text { Fast } \\
\text { Pyrolysis } \\
\text { Reactor } \\
\text { Type }\end{array}$ & $\begin{array}{c}\text { Temperature } \\
\left({ }^{\circ} \mathrm{C}\right)\end{array}$ & $\begin{array}{c}\text { Moisture } \\
\text { (wt \%) }\end{array}$ & $\begin{array}{c}\text { Volatiles } \\
\text { (wt \%) }\end{array}$ & $\begin{array}{l}\text { Fixed C } \\
\text { (wt \%) }\end{array}$ & $\begin{array}{c}\text { Ash } \\
\text { (wt \%) }\end{array}$ & $\underset{\text { (wt } \%)}{C}$ & $\underset{(w t \%)}{H}$ & $\underset{(w t \%)}{N}$ & $\begin{array}{c}0^{*} \\
(w t \%)\end{array}$ & $\begin{array}{c}\text { Particle } \\
\text { density } \\
(\mathrm{g} / \mathrm{cc})\end{array}$ & $\begin{array}{l}\text { S.A.** } \\
\left(m^{2} / g\right)\end{array}$ & $\begin{array}{l}H H V^{* * *} \\
(\mathrm{M} / \mathrm{kg})\end{array}$ \\
\hline Corn Stover & $\begin{array}{c}\text { Fluidized } \\
\text { Bed }\end{array}$ & 500 & 6.4 & 36 & 41 & 16 & 55 & 4 & 1 & 23 & 1.6 & 7.7 & 20.5 \\
\hline Corn Stover & $\begin{array}{c}\text { Fluidized } \\
\text { Bed }\end{array}$ & 500 & 4.8 & 24 & 31 & 40 & 38 & 3 & 1 & 16 & 1.9 & 8.7 & 14.4 \\
\hline $\begin{array}{l}\text { Loblolly } \\
\text { Pine }\end{array}$ & Free Fall & 485 & 4 & 45 & 39 & 12 & 61 & 4 & 0 & 22 & 1.7 & 2.4 & 22.9 \\
\hline $\begin{array}{l}\text { Loblolly } \\
\text { Pine }\end{array}$ & Free Fall & 550 & 4.3 & 31 & 60 & 5 & 74 & 4 & 1 & 16 & 1.5 & 3.3 & 27.9 \\
\hline Red Oak & $\begin{array}{c}\text { Fluidized } \\
\text { Bed }\end{array}$ & 400 & 1.4 & 28 & 35 & 36 & 47 & 3 & 0 & 14 & 1.8 & 1.0 & 18.4 \\
\hline Red Oak & $\begin{array}{c}\text { Fluidized } \\
\text { Bed }\end{array}$ & 450 & 2.5 & 45 & 31 & 21 & 67 & 4 & 0 & 8 & 1.6 & 2.2 & 25.5 \\
\hline Red Oak & $\begin{array}{c}\text { Fluidized } \\
\text { Bed }\end{array}$ & 500 & 1.8 & 25 & 35 & 38 & 51 & 2 & 0 & 9 & 1.9 & 1.5 & 18.6 \\
\hline Red Oak & $\begin{array}{c}\text { Fluidized } \\
\text { Bed }\end{array}$ & 550 & 1.2 & 14 & 29 & 55 & 40 & 2 & 0 & 3 & 2.0 & 1.1 & 14.3 \\
\hline Red Oak & Free Fall & 450 & 4.3 & 31 & 64 & 2 & 77 & 4 & 0 & 17 & 1.5 & 2.9 & 28.6 \\
\hline Red Oak & Free Fall & 550 & 4.3 & 28 & 66 & 2 & 77 & 4 & 0 & 17 & 1.6 & 6.0 & 29 \\
\hline Red Oak & Free Fall & 600 & 4.8 & 29 & 65 & 2 & 78 & 4 & 0 & 16 & 1.5 & 4.7 & 29 \\
\hline Switchgrass & $\begin{array}{c}\text { Fluidized } \\
\text { Bed }\end{array}$ & 500 & 2.6 & 39 & 28 & 31 & 50 & 3 & 1 & 14 & 1.7 & 7.9 & 19 \\
\hline
\end{tabular}


Table 2. Expanded list of fast pyrolysis biochars selected for testing based on feedstock, reactor configuration, reaction conditions and biomass pretreatments

\begin{tabular}{|c|c|c|c|c|}
\hline Short-ID & Feedstock & Reactor & Temp. $\left({ }^{\circ} \mathrm{C}\right)$ & Pretreatment \\
\hline 616 & corn stover & fluid bed F.P. & 500 & Clean-harvest technique \\
\hline 617 & corn stover & fluid bed F.P. & 500 & Conventional harvest technique \\
\hline 910 & loblolly pine & fluid bed F.P. & 485 & Not washed \\
\hline 918 & loblolly pine & fluid bed F.P. & 485 & Torrified@215 C \\
\hline 1027 & loblolly pine & fluid bed F.P. & 485 & Torrified@215 C \\
\hline 1031 & loblolly pine & fluid bed F.P. & 485 & Torrified@250C \\
\hline 831 & loblolly pine & free fall F.P. & 550 & Washed \\
\hline 1104 & red oak & PDU fluid bed F.P. & 400 & \\
\hline 1111 & red oak & PDU fluid bed F.P. & 450 & \\
\hline 1026 & red oak & PDU fluid bed F.P. & 500 & \\
\hline 1119 & red oak & PDU fluid bed F.P. & 550 & \\
\hline 113 & red oak & free fall F.P. & 550 & \\
\hline 401 & red oak & free fall F.P. & 450 & \\
\hline 403 & red oak & free fall F.P. & 600 & $500 \mu \mathrm{m}$ grind \\
\hline \multirow[t]{3}{*}{407} & red oak & free fall F.P. & 600 & $300 \mu \mathrm{m}$ grind \\
\hline & red oak & auger F.P. & & \\
\hline & switchgrass & fluid bed F.P. & 500 & $\mathrm{H}_{2} \mathrm{SO}_{4}$-treated \\
\hline \multirow[t]{5}{*}{427} & switchgrass & fluid bed F.P. & 500 & $\mathrm{H}_{3} \mathrm{PO}_{4}$-treated \\
\hline & switchgrass & free fall F.P. & 500 & N level 1 \\
\hline & switchgrass & free fall F.P. & 500 & Nlevel 2 \\
\hline & switchgrass & free fall F.P. & 500 & N level 3 \\
\hline & switchgrass & free fall F.P. & 500 & N level 4 \\
\hline
\end{tabular}


Artículo/Article Sección/Section C

Vol. 13, nro. 2 ID: 2314

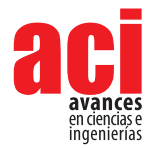

Fast Pyrolysis Biochar Flammability Behavior for Handling and Storage del Campo / Brumm / Keren (2021)

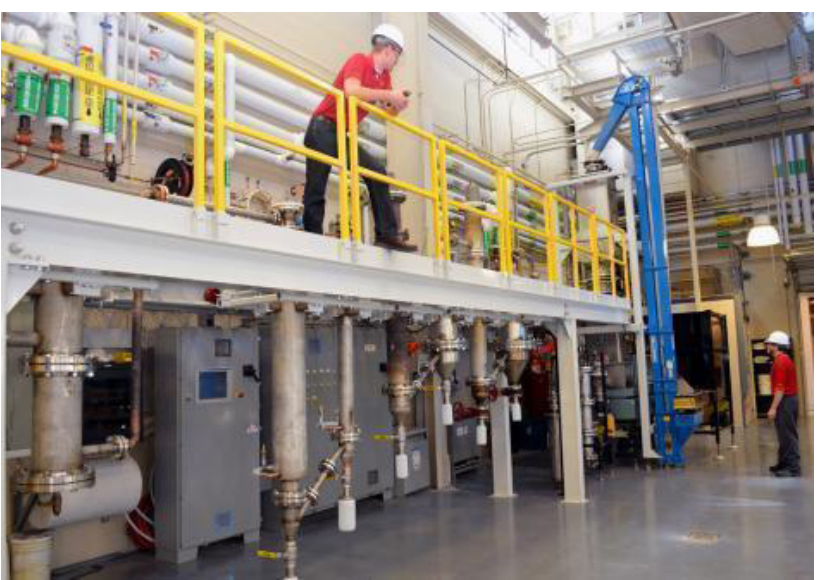

$2 A$

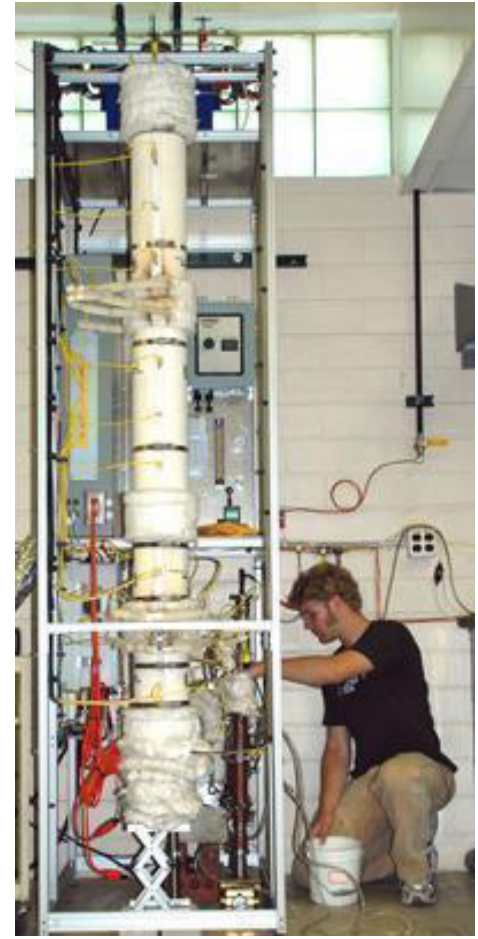

2B

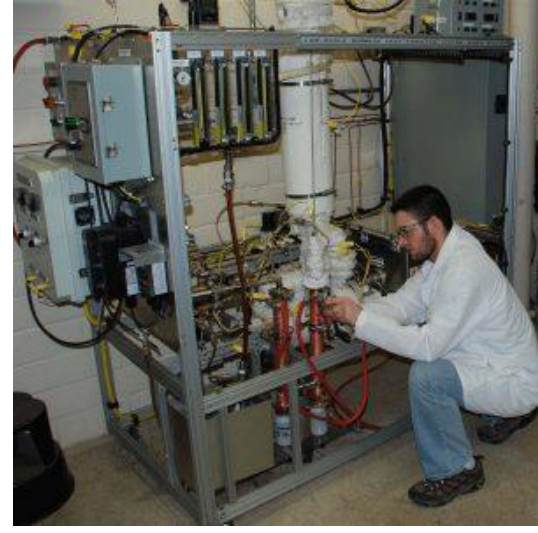

$2 C$

Figure 2. Fluidized bed reactor (2A), free fall reactor (2B), auger reactor (2C). Pictures from lowa State University Center for Sustainable Environmental Technologies 
The results obtained from this study were then compared to data on other carbonaceous materials such as gasification, slow pyrolysis and typical charcoal that are produced with different reactor types from commercial production facilities or from other research institutions [20].

From the three flammable categories in Hazardous Materials Class, initial laboratory testing suggested that fast pyrolysis biochars may be classified as Flammable Solids (4.1) and Spontaneously Combustible (4.2). Literature indicates that similar types of carbonaceous materials are flammable when wet (4.3) and can result in self-combustion processes. It is not clear, however, what the circumstances or the specific properties of the material are that can trigger such behavior [15]. The materials used in this study did not present any dangerous behavior when wet. However, the Code of Federal Regulation CFR 177.838 paragraph (b) "articles to be kept dry" states that charcoal screenings, ground, crushed or pulverized charcoal and lump charcoal are dangerous materials and should be kept dry as water can create hot spots and start a fire. Again, none of the materials here presented any visible reaction with water, so they were not considered Class 4.3.

\section{Ignitability of Solids (EPA 1030)}

In order to assess whether biochars fall under the Flammable Solids category (Class 4.1), a preliminary screening method defined by U.S. DoT/UN Transportation of Dangerous Goods (also referred to as Ignitability of Solids EPA 1030) was used [17]. If the material is identified as a flammable solid, there are further steps needed to classify the type of flammable solid it corresponds to. This preliminary test is performed over a powder triangular train of $250 \mathrm{~mm}$ long by $20 \mathrm{~mm}$ at the base and $10 \mathrm{~mm}$ high placed on a low-conductive plate. After an ignition source is applied to one end of the test strip, if combustion propagates along $200 \mathrm{~mm}$ of the strip within $2 \mathrm{~min}$ (for non-metallic materials), then it is classified as ignitable (or flammable) solid. If the results of the preliminary test indicate the sample is flammable, then it is subjected to an additional test for burning rate along $100 \mathrm{~mm}$ distance. If the burning rate is faster than $2.2 \mathrm{~mm} / \mathrm{s}$, the sample is considered Class 4.1 flammable solid (EPA 1030 test method). To test how moisture affects flammability, distilled water was added to achieve different moisture levels after the samples were dried. To assure moisture equilibrium was reached throughout the sample, flammability tests were conducted a few days after adding water to the samples. Pearson correlation coefficient was used to understand if there was any correlation between flammability and chemical and physical characteristics.

\section{Flammability Potential Screening Analysis of Wastes (ASTM D4982-95)}

Flammability Potential Screening was used to analyze the flammability potential of the samples and the vapors released from these samples (ASTM D4982-95) [18]. By using this particular test method, it is possible to not only gain information about the biochars' flammability with a fast screening test but also to understand the effect of moisture on this characteristic.

These test methods are to complement quantitative analytical techniques for determining flammability. The tests can be used with slurry, liquid and solid wastes to evaluate if the material has potential to produce or sustain fire (Figure 3). The procedure is implemented 
utilizing two methods in which the material is subjected to ignition: Test Method A "Test Sample Exposed to Heat and Flame" and Test Method B "Test Sample Exposed to Spark Source."Test Method A has two components. The first component relates to the sample's ability to release volatile vapors. A flame is positioned perpendicularly on top of the sample for three seconds. If a spark is visible, the sample is labeled as a positive flammability potential. Samples were tested as they were initially received by the laboratory. In addition, samples were dried at $103^{\circ} \mathrm{C}$ for $24 \mathrm{~h}$ to remove any moisture. When the samples cooled to room temperature, both test methods were repeated.

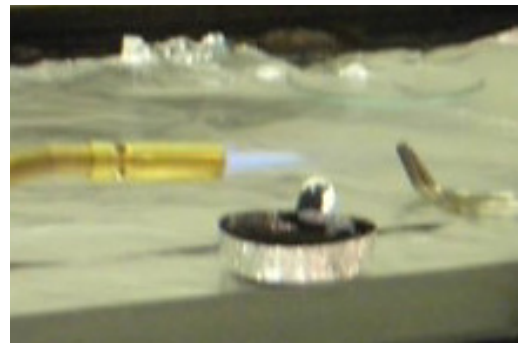

$3 A$

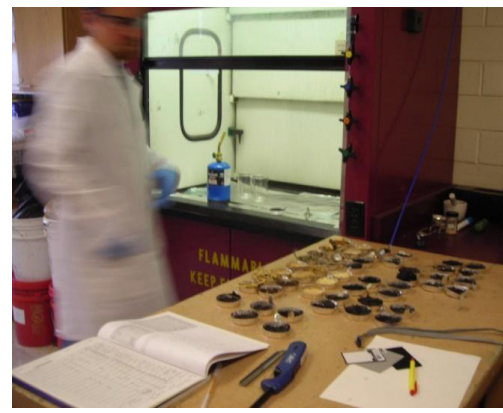

$3 C$

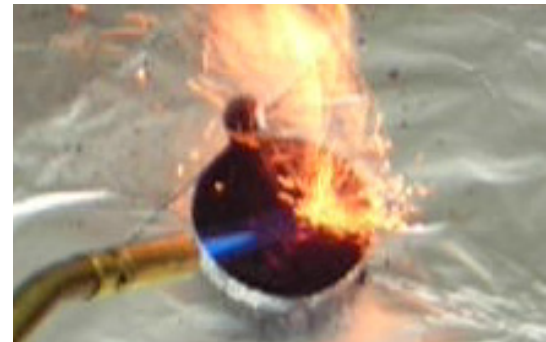

3B

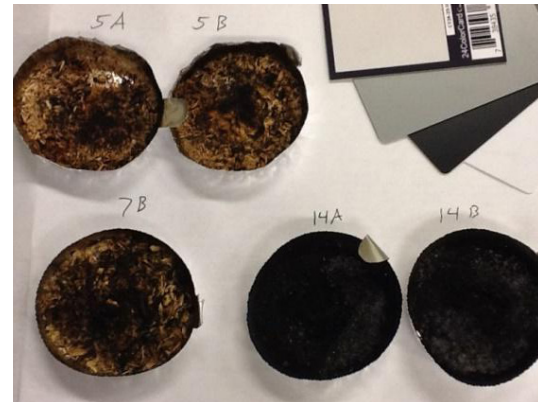

3D

Figure 3. Example of flammability potential ASTM D4982, sample preparation and procedure

\section{Biochar chemical and physical properties}

Proximate analysis (thermogravimetric analysis) was performed using a thermogravimetric analyzer (TGA) instrument (Mettler Toledo, USA). The energy content of the samples (higher heating value) was obtained using a Parr oxygen bomb calorimeter (Parr Instrument Company, USA). The elemental analysis was performed using Leco TruSpec (LECO Corporation, St. Joseph, MI, USA) for carbon, hydrogen, nitrogen and sulfur (CHNS), and the determination of oxygen was made by mass difference. Ethylenediamine-tetra-acetic acid (EDTA) was used as the reference standard for the quantification of carbon, hydrogen, and nitrogen. Sulfur reference material for coal was used for sulfur quantification. All standards were obtained from Leco Corporation. Particle density was measured with a helium pycnometer (Pentapycnometer, Quantachrome Instruments, Boynton Beach, FL, 
USA) using degassed samples from the Brunauer, Emmett, and Teller BET analysis. Surface area analysis was performed with $4 \mathrm{~g}$ samples degassed for $4 \mathrm{~h}$ at $300^{\circ} \mathrm{C}$ under vacuum at a pressure lower or equal to $100 \mathrm{~Pa}$. (BET) using $\mathrm{N}_{2}$ gas in a Quantachrome NOVA 4200e Gas Sorption Analyzer (Quantachrome Instruments, Boynton Beach, FL, USA). Five adsorption points were measured in the range of 0.05 to $0.3 \mathrm{P} / \mathrm{P}$.

\section{Method sensitivity}

Due to the sensitivity of the methods and the various material formulations, tests were performed without altering the physical properties of the sample as this can alter the results and subsequently the classification $[16,17]$. From a methodology perspective, it is important to clarify that samples should be tested when received without drying, milling, and sieving before flammability analyses are performed. It is very important to have uniform sampling procedure to obtain a representative sample when collecting the material at the facility as well as when preparing the sample for testing. Moisture measurement can significantly affect the results. Moisture and particle size (minimum descriptive format such as fine powder, sand, coarse granules) should be reported as accurately as possible for correct interpretation. Particle size has been reported to affect burn rate and also the ignitability of the material [17]

\section{RESULTS AND DISCUSSION}

\section{Physico-chemical characterization of the biochars made with different operating conditions and reactors}

Biochar properties vary significantly in comparison to other carbonaceous materials [21], and the flammability will be associated with the biochar properties. Additionally, flammability assessment will depend on the method that was used in the evaluation. This study evaluates a handful of different materials, yet further research is needed in order to better understand biochar properties and the conditions that could trigger unsafe flammable conditions.

The chemical and physical properties of biochar can vary widely depending on the feedstock and pyrolysis conditions. In order to broaden the chemical composition and flammability results in this study, a wide range of carbonaceous materials were obtained from various feedstocks, reactor configurations and processing conditions (Table 1). For example, carbon content from this set of samples varied from 40 to $78 \mathrm{wt} \%$, ash content from 2 to $40 \mathrm{wt} \%$, volatile content from 14 to $40 \mathrm{wt} \%$, surface area from 1.0 to $8.7 \mathrm{~m}^{2} / \mathrm{g}$, and energy contents from 14.4 to $29 \mathrm{MJ} / \mathrm{kg}$. Flammability characteristics were examined, and results were compared to those cited in the literature, addressing both flammable and non-flammable carbonaceous materials.

\section{EPA Test Method 1030 Ignitability of Solids}

This method evaluates whether samples are flammable (first tier of classification). If the sample propagates over $200 \mathrm{~mm}$ of the powder train in 2 minutes, then it is subjected to a burning rate test. Wastes are considered flammable if the burning rate is higher than 
$2.2 \mathrm{~mm} / \mathrm{s}$ and for metals $0.17 \mathrm{~mm} / \mathrm{s}$ (Table 3 and Table 4). The parameter "time to ignite" here presents the differences in response between materials when in contact with a flame. The biomass developed a clear flame and was simple to identify ignition, but the other materials were not clear as their flames were not truly developed (combustion of ambers).

Table 3. Flammability results from various carbon products in accordance with EPA 1030 method

\begin{tabular}{|c|c|c|c|c|}
\hline $\begin{array}{c}\text { Materials } \\
\text { (\# samples) }\end{array}$ & Formulation & Flammable & $\begin{array}{c}\text { Time to lgnite } \\
\text { (s) } \\
\pm \text { S.D. }\end{array}$ & $\begin{array}{c}2 \mathrm{~min} \\
\text { propagation } \\
(\mathrm{mm}) \\
\pm \text { S.D.* }\end{array}$ \\
\hline Activated Carbon (2) & Fine powder & No & $53 \pm 18$ & $1 \pm 1^{* *}$ \\
\hline Gasification Char (2) & Fine powder & No & $52 \pm 25$ & $3 \pm 4^{* *}$ \\
\hline Slow P. Char (3) & Fine powder & No & $41 \pm 24$ & $11 \pm 7^{* *}$ \\
\hline Fast P. Biochar (19) & Fine powder & No & $39 \pm 4$ & $21 \pm 24$ \\
\hline Biomass (5) & Fine powder & No & $18 \pm 4$ & $4 \pm 3$ \\
\hline
\end{tabular}

Table 4. Expanded EPA 1030 Ignitability of Solids

\begin{tabular}{|c|c|c|}
\hline Row Labels & Average of Time to lgnite (s) & Average of Propagation \\
\hline Activated Carbon & 53 & 1 \\
\hline McMaster AC & 48 & 0 \\
\hline NORIT AC & 58 & 1 \\
\hline Biochar & 40 & 17 \\
\hline Char 1-20101104 & 40 & 9 \\
\hline Char 1-20101111 & 42 & 10 \\
\hline Char 1-20101026 & 40 & 3 \\
\hline Red Oak BC 1-201011191-C & 40 & 0 \\
\hline Clear corn Stover BC 8-20090616A & 43 & 26 \\
\hline Corn Stover BC 8-20090617A & 40 & 19 \\
\hline Loblolly Pine BC 8-20080910 & 40 & 17 \\
\hline RO 7-20090401A & 40 & 14 \\
\hline RO 7-20090113A & 40 & 13 \\
\hline RO 7-20090403A & 40 & 11 \\
\hline Switchgrass BC 7-00720411 & 30 & 27 \\
\hline
\end{tabular}




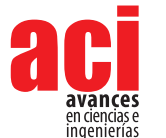

\begin{tabular}{|c|c|c|}
\hline Row Labels & Average of Time to lgnite (s) & Average of Propagation \\
\hline Switchgrass BC 7-20110412 & 40 & 20 \\
\hline Switchgrass BC 7-20111107 & 33 & 23 \\
\hline Washed L Pine BC 7-20090831A & 40 & 12 \\
\hline $\mathrm{RO} B C 6-22-12$ & 40 & 9 \\
\hline SG 0\% Moisture & 40 & 95 \\
\hline SG $10 \%$ BC & 40 & 22 \\
\hline SG BC $20 \%$ & 40 & 20 \\
\hline $\mathrm{RO} B C \mathrm{~B} \%$ & 41 & 8 \\
\hline $\mathrm{RO} B C 10 \%$ & 40 & 2 \\
\hline $\mathrm{RO} B C 20 \%$ & 41 & 4 \\
\hline CS 0\% moisture & 37 & 70 \\
\hline CS BC $10 \%$ & 41 & 14 \\
\hline CS BC $20 \%$ & 40 & 17 \\
\hline LPBC 0\% & 40 & 13 \\
\hline LP 10\% BC & 40 & 11 \\
\hline LP BC 20\% & 43 & 9 \\
\hline Biomass & 18 & 4 \\
\hline Corn Stover BM & 19 & 5 \\
\hline Maple Sawdust & 29 & 8 \\
\hline Maple Shavings & 19 & 7 \\
\hline Red Oak BM & 16 & 4 \\
\hline Switchgrass BM & 16 & 2 \\
\hline Slow P Char & 41 & 11 \\
\hline Artichar 1 & 20 & 5 \\
\hline Artichar 2 & 40 & 17 \\
\hline Artichar 3 & 64 & 11 \\
\hline Gasification char & 52 & 3 \\
\hline Char 1-11-12-12 (Broer) & 40 & 5 \\
\hline Karl Broer 1-07-13 catch & 70 & 1 \\
\hline Grand Total & 39 & 13 \\
\hline
\end{tabular}


None of the materials were considered intrinsically flammable. Note that fast pyrolysis biochars had higher propagation with roughly one-fifth of the required trajectory (200 $\mathrm{mm}$ ) burnt in two minutes. Activated carbon had $1 \mathrm{~mm}$ (almost no propagation), but gasification chars propagated slightly. Biomass tested here were materials with similar properties to those used for making the fast pyrolysis biochars (corn stover, red oak, loblolly pine, and switchgrass). The biomass presented shorter propagation possibly due to the higher moisture contents (between 10-15\% w.b.), its finely ground nature, and the packed conditions used for the testing. Additionally, note that biomass demonstrated the least "time to ignite" when exposed to flame. The flames created from the proximity to the heat source for the short ignition time did not result in complete particle ignition.

The ignition time was problematic to determine as both materials presented distinct responses to the contacts with the flames. Biomass ignition was the point where flames became visible, while biochar ignition was the point where the material glowed red and became sufficiently hot to propagate. As such, ignition time was a subjective measurement dependent on the operator. Despite that, biomass ignition time was half of any observed biochar ignition time, and the ignition was clearly visible through the development of flames.

Pyrolyzed biochar demonstrated greater propagation than gasification char. In comparison, activated carbon almost entirely failed to propagate. This may be attributable to the graphite-like chemical structure and the lower content of volatiles, which reduce the likelihood that activated carbon will react and combust due to the recalcitrant aromatic structure. The standard deviations of propagation rates are large for fast pyrolysis biochars due to the large chemical and property characteristics associated with the different operating conditions (temperatures from 400 to $600^{\circ} \mathrm{C}$ ), different reactors, resident times and feedstocks.

Figure 4 shows the propagation results of four fast pyrolysis of biochar feedstocks (switchgrass, corn stover, red oak and loblolly pine) produced with the same conditions (in a fluidized bed at $500^{\circ} \mathrm{C}$ ) but with different moisture content after storage. As can be expected, flame front in dry biochars propagated considerably faster than in moist biochars. Switchgrass and corn stover (herbaceous) biochars flame propagation were higher than wood types at the same pyrolysis temperature conditions and moistures. Therefore, a very important consideration in assessing flammability propagation is the moisture content at the time that the measurement is completed. Moisture can significantly differ according to production time, time of storage, and time of sampling. Therefore, special considerations must be made when taking representative samples, handling the sample, assuring adequate testing procedure, and communicating the results. 

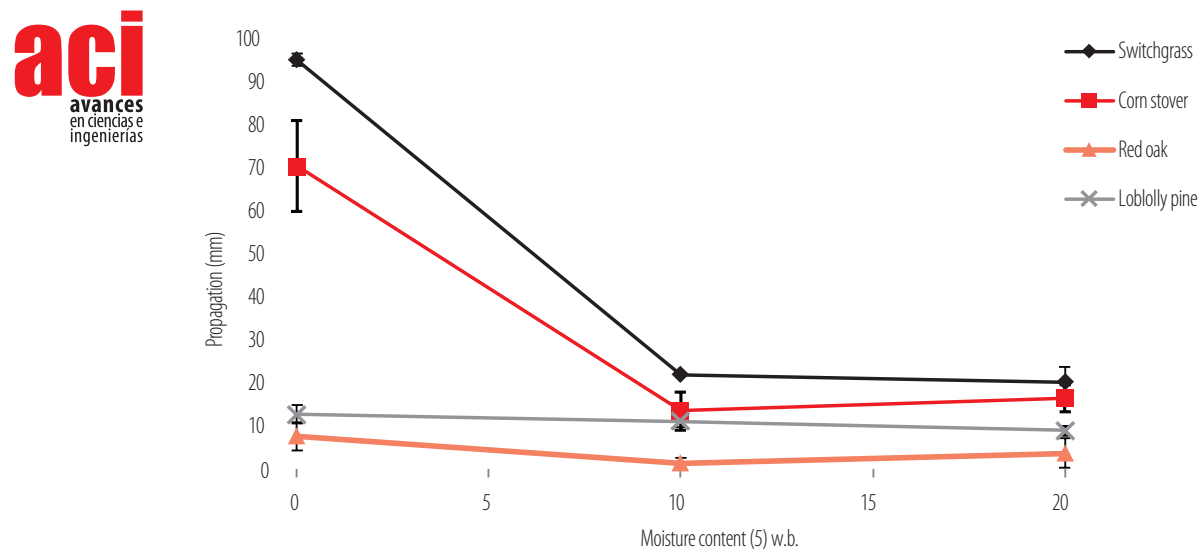

Figure 4. Fast pyrolysis biochar propagation by feedstock species and its relationship with moisture content

Bone dry corn stover and switchgrass fast pyrolysis biochar were not flammable (less than $200 \mathrm{~mm}$ of propagation in $2 \mathrm{~min}$ ), but in comparison to the other materials, the propagation was much longer. For bone dry materials, the traveled distance was 95 $\mathrm{mm}$ for switchgrass and $70 \mathrm{~mm}$ for corn stover, while the propagation in both woody feedstocks was considerably lower, $13 \mathrm{~mm}$ for loblolly pine and $8 \mathrm{~mm}$ for red oak. The difference in flammability between bone dry biochars and different feedstocks is quite large. However, an addition of 10\% moisture to the biochar reduced the propagation distance by more than $25 \%$ in both switchgrass and corn stover.

Table 5 presents Pearson correlation coefficients for flammability propagation and chemical constituents performed for all the fast pyrolysis biochars (listed in Table 6).

Table 5. Pearson correlation coefficient for the smoldering propagation of fast pyrolysis biochars and various chemical properties

\begin{tabular}{|c|c|}
\hline Variable & Pearson correlation \\
\hline Volatiles (wt \%) & 0.51 \\
\hline Fixed C (wt \%) & 0.20 \\
\hline Ash & -0.47 \\
\hline C & 0.16 \\
\hline $\mathrm{H}$ & 0.73 \\
\hline $\mathrm{N}$ & 0.82 \\
\hline O & 0.88 \\
\hline Particle $\rho$ & -0.50 \\
\hline Surface area $\left(\mathrm{m}^{2} / \mathrm{g}\right)$ & 0.77 \\
\hline $\mathrm{HHV}(\mathrm{MJ} / \mathrm{kg})$ & 0.18 \\
\hline
\end{tabular}


Table 6. Results from chemical characterizations of selected biochars (see Table 1). Moisture, volatiles, fixed carbon and ash contents and higher heating values (HHV) are on an as-received basis; all other results are reported on a dry basis. Oxygen content determined by difference. $P=$ density, $S . A .=$ surface area, $C . S .=$ corn stover, L.P. $=$ loblolly pine, R.O. = red oak, S.G. $=$ switchgrass, F.F. $=$ free fall reactor, $\mathrm{PDU}=$ process development unit reactor

\begin{tabular}{|c|c|c|c|c|c|c|c|c|c|c|c|c|}
\hline ID & Description & $\begin{array}{c}\text { Moisture } \\
\text { wt } \%\end{array}$ & $\begin{array}{c}\text { Volatiles } \\
\text { wt } \%\end{array}$ & $\begin{array}{l}\text { Fixed C } \\
\text { wt } \%\end{array}$ & $\begin{array}{l}\text { Ash } \\
\text { wt } \%\end{array}$ & $\underset{\text { wt } \%}{C}$ & $\underset{\text { wt } \%}{\mathrm{H}}$ & $\underset{\text { wt } \%}{\mathrm{~N}}$ & $\begin{array}{c}0 \\
\text { wt } \%\end{array}$ & $\begin{array}{c}\text { Particle } \rho \\
(\mathrm{g} / \mathrm{cc})\end{array}$ & $\underset{\left(\mathrm{m}^{2} / \mathrm{g}\right)}{\text { S.A. }}$ & $\begin{array}{c}\text { HHV } \\
(\mathrm{MJ} / \mathrm{kg})\end{array}$ \\
\hline 616 & Clean C.S. & 6.4 & 36.3 & 41.1 & 16.3 & 54.6 & 4.2 & 0.5 & 23.3 & 1.57 & 7.7 & 20.5 \\
\hline 617 & Reg.C.S. & 4.8 & 23.9 & 31.3 & 40.1 & 38.1 & 2.9 & 0.6 & 16.3 & 1.88 & 8.7 & 14.4 \\
\hline 910 & L.P. no treat & 4.0 & 45.0 & 39.1 & 11.9 & 61.0 & 3.9 & 0.4 & 22.3 & 1.72 & 2.4 & 22.9 \\
\hline 918 & L.P. torr 215C & 4.9 & 42.8 & 43.1 & 9.3 & 62.7 & 4.1 & 0.5 & 22.9 & 1.55 & 2.4 & 23.6 \\
\hline 1027 & L.P. torr 215C & 4.2 & 36.1 & 52.5 & 7.2 & 65.4 & 4.0 & 0.2 & 22.8 & 1.50 & 2.9 & 24.8 \\
\hline 1031 & L.P. torr 250C & 3.9 & 33.9 & 50.7 & 11.5 & 63.5 & 4.0 & 0.3 & 20.2 & 1.53 & 2.2 & 24.1 \\
\hline 831 & L.P.F.F. wash $550 \mathrm{C}$ & 4.3 & 31.3 & 59.6 & 4.7 & 74.2 & 4.1 & 0.5 & 16.3 & 1.47 & 3.3 & 27.9 \\
\hline 1104 & R.0.PDU 400C & 1.4 & 28.1 & 34.9 & 35.6 & 47.0 & 2.7 & 0.1 & 14.1 & 1.77 & 1.0 & 18.4 \\
\hline 1111 & R.0.PDU $450 C$ & 2.5 & 44.6 & 31.4 & 21.4 & 66.8 & 3.6 & 0.2 & 7.5 & 1.60 & 2.2 & 25.5 \\
\hline 1026 & R.0. PDU 500C & 1.8 & 25.4 & 35.0 & 37.7 & 50.7 & 2.3 & 0.1 & 8.5 & 1.92 & 1.5 & 18.6 \\
\hline 1119 & R.0.PDU 550C & 1.2 & 14.4 & 29.1 & 55.3 & 39.5 & 1.6 & 0.1 & 2.9 & 2.02 & 1.1 & 14.3 \\
\hline 113 & R.O.F.F. $550 \mathrm{C}$ & 4.3 & 28.0 & 66.0 & 1.6 & 77.4 & 3.8 & 0.3 & 16.8 & 1.63 & 6.0 & 29.0 \\
\hline 401 & R.0. F.F. $450 \mathrm{C}$ & 4.3 & 30.5 & 63.7 & 1.5 & 76.6 & 4.0 & 0.4 & 17.4 & 1.50 & 2.9 & 28.6 \\
\hline 403 & R.O.F.F. $600 \mathrm{CL}$ & 4.8 & 28.7 & 64.7 & 1.9 & 77.5 & 3.9 & 0.4 & 16.2 & 1.49 & 4.7 & 29.0 \\
\hline 407 & R.O.F.F. $600 \mathrm{CS}$ & 4.3 & 29.4 & 64.7 & 1.5 & 76.5 & 3.9 & 0.4 & 17.6 & 1.52 & 4.7 & 28.8 \\
\hline 427 & S.G. H3PO4 & 2.6 & 38.7 & 27.9 & 30.8 & 50.4 & 3.3 & 0.8 & 13.9 & 1.68 & 7.9 & 19.0 \\
\hline
\end{tabular}

Note: L.P. $=$ refers to Loblolly pine, R.O.= refers to red oak, S.G.= Switchgrass, C.S.= Corn Stover. Torr $=$ terrified and later pyrolyzed, wash= acid wash to remove ash, $\mathrm{H} 3 \mathrm{PO} 4=$ acid washed with phorsphoric acid before pyrolysis

Flammability propagation had a high correlation for oxygen content and surface area in fast pyrolysis biochars. Both correlations line up with expectations. Note, however, that the surface area range is small in comparison with other carbon materials. All surface areas were less than $10 \mathrm{~m}^{2} / \mathrm{g}$ while other carbons could easily reach 500 or $1000 \mathrm{~m}^{2} / \mathrm{g}$ [21]. A medium correlation coefficient between propagation and volatile content was seen with $r^{2}=0.51$ similar to Zhao et al [1 1]. It is important to note that Zhao and his colleagues studied different types of biochars, while in this study, only fast pyrolysis biochars with a smaller range of volatile variability were tested. Although nitrogen content showed high correlation as well, the range of results for nitrogen content between the samples was from 0.1 to $0.8 \%$ with an average of $0.3 \%$ of the total elemental composition. Thus, it is very likely that the error of the measure and small dispersion of values could be as large as the correlation itself.

It was expected that the ash content of the biochar would have a significant negative correlation with flammability as it would decrease the energy density of the material similarly to graphite and ash impurities [10]. The fact that there are more minerals and less carbon in the biochar was presumed to be a factor that would lower the energy 
density and potential flammability and reduce the propagation rate. The results, however, showed a negative correlation with flammability as expected, but medium to low correlation -0.47 .

\section{ASTM D4982 Standard Test Methods for Flammability Potential Screening Analysis of Waste}

Flammability was further evaluated using Standard Test Methods for Flammability Potential Screening Analysis of Waste ASTM D4982 (Table 7). In this test, a sample was considered flammable if any of the sections and methods from these tests resulted positive (flammable). Although this method is fairly subjective as it is difficult to clearly assess if the material is lit or not with decaying embers, it was determined that biochars, biomasses, and the coal samples are flammable according to this test. It is important to note here that their original biomass showed much higher flammability potential than their produced biochars, and thus required extinguishing the sample after the test was performed. Section 1 test method A, sample exposed to heat with the flame on top of the sample, and test method B, sample exposed to spark source, resulted in negative flammability characteristics for all materials. However, when implementing Section 2 test method A, with direct contact with flames for 10 seconds, almost all biochars produced embers that were lit for at least 20 seconds. No differences were observed in flammability potential between the dried samples and the samples with their original moisture content. The lack of differences in flammability response was likely due to the small amount of moisture present in the original biochar samples (less than $5.5 \mathrm{wt} \%$ for all the biochar materials).

Table 7. ASTM D4982 Flammability potential of 26 materials with samples as received and dried, evaluated under Test methods $A$ and $B$

\begin{tabular}{|c|c|c|c|c|c|c|c|c|c|}
\hline \multirow[b]{3}{*}{$\begin{array}{c}\text { Biomass/ } \\
\text { Biochar } \\
\text { Materials }\end{array}$} & \multicolumn{4}{|c|}{ As received } & \multirow{3}{*}{$\begin{array}{l}\text { Method B } \\
3 \text { strikes }\end{array}$} & \multirow{2}{*}{\multicolumn{3}{|c|}{$\begin{array}{c}\text { Dried } \\
\text { Method A }\end{array}$}} & \multirow{3}{*}{$\begin{array}{l}\text { Method B } \\
3 \text { strikes }\end{array}$} \\
\hline & \multirow[b]{2}{*}{$\begin{array}{c}\text { Moisture } \\
(\%) \text { w.b. }\end{array}$} & \multicolumn{3}{|c|}{ Method A } & & & & & \\
\hline & & $\begin{array}{c}\text { Above } \\
(35)\end{array}$ & $\begin{array}{c}\text { Contact } \\
(10 s)\end{array}$ & Notes & & $\begin{array}{c}\text { Above } \\
\text { (3s) }\end{array}$ & $\begin{array}{c}\text { Contact } \\
\text { (10s) }\end{array}$ & Notes & \\
\hline Corn Cob Biomass & $6.9 \%$ & N & P & $\begin{array}{l}\text { Extinguished } \\
\text { Flames }\end{array}$ & N & N & P & $\begin{array}{c}\text { Extinguished } \\
\text { Flames }\end{array}$ & N \\
\hline Corn Stover Biomass & $4.9 \%$ & N & P & $\begin{array}{l}\text { Extinguished } \\
\text { Flames }\end{array}$ & N & N & P & & N \\
\hline Dry Compost & $7.4 \%$ & N & $P$ & & N & N & P & & N \\
\hline $\begin{array}{c}\text { Loblolly Pine } \\
\text { Biomass }\end{array}$ & $5.5 \%$ & N & P & $\begin{array}{l}\text { Extinguished } \\
\text { Flames }\end{array}$ & N & N & P & $\begin{array}{c}\text { Extinguished } \\
\text { Flames }\end{array}$ & N \\
\hline $\begin{array}{c}\text { Poplar Sawdust } \\
\text { Biomass }\end{array}$ & $5.5 \%$ & N & P & $\begin{array}{l}\text { Extinguished } \\
\text { Flames }\end{array}$ & N & N & P & & N \\
\hline RDF Biomass & $2.1 \%$ & N & P & & N & N & P & $\begin{array}{c}\text { Extinguished } \\
\text { Flames }\end{array}$ & N \\
\hline $\begin{array}{l}\text { Red Oak Biomass } \\
\quad<180 \text { um }\end{array}$ & $14.8 \%$ & N & P & & N & N & P & & N \\
\hline
\end{tabular}




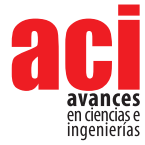

\begin{tabular}{|c|c|c|c|c|c|}
\hline \multirow[b]{3}{*}{$\begin{array}{c}\text { Biomass/ } \\
\text { Biochar } \\
\text { Materials }\end{array}$} & \multicolumn{4}{|c|}{ As received } & \multirow{3}{*}{$\begin{array}{l}\text { Method B } \\
\text { 3 strikes }\end{array}$} \\
\hline & \multirow[b]{2}{*}{$\begin{array}{l}\text { Moisture } \\
(\%) \text { w.b. }\end{array}$} & \multicolumn{3}{|c|}{ Method A } & \\
\hline & & $\begin{array}{c}\text { Above } \\
\text { (3s) }\end{array}$ & $\begin{array}{c}\text { Contact } \\
(10 \mathrm{~s})\end{array}$ & Notes & \\
\hline $\begin{array}{c}\text { Red Oak Biomass } \\
\text { Powder }\end{array}$ & $11.4 \%$ & N & P & & N \\
\hline $\begin{array}{l}\text { Switchgrass Biomass } \\
\text { Powder }\end{array}$ & $2.6 \%$ & N & P & $\begin{array}{l}\text { Extinguished } \\
\text { Flames }\end{array}$ & $\mathrm{N}$ \\
\hline $\begin{array}{c}\text { Switchgrass Pellets } \\
\text { Biomass }\end{array}$ & $7.5 \%$ & N & P & & N \\
\hline Coal & $5.8 \%$ & N & P & & N \\
\hline Fly Ash & $2.0 \%$ & N & N & & N \\
\hline Coke & $1.0 \%$ & N & N & & N \\
\hline $\begin{array}{c}\text { Corn Cobs } \\
\text { Gasification Char }\end{array}$ & $1.3 \%$ & N & P & $\begin{array}{l}\text { Extinguished } \\
\text { Flames }\end{array}$ & N \\
\hline $\begin{array}{l}\text { Corn Stover F.P. } \\
\text { Biochar 500C }\end{array}$ & $1.2 \%$ & N & N & & N \\
\hline $\begin{array}{l}\text { Corn Stover S.P. } \\
\text { Biochar 500C }\end{array}$ & $3.0 \%$ & N & P & $\begin{array}{l}\text { Extinguished } \\
\text { Flames }\end{array}$ & N \\
\hline $\begin{array}{l}\text { ICM Mixed Woods } \\
\text { Gasification Char }\end{array}$ & $2.2 \%$ & $N$ & P & & N \\
\hline $\begin{array}{l}\text { Loblolly Pine F.P. } \\
\text { Biochar } 485 C\end{array}$ & $3.1 \%$ & $\mathrm{~N}$ & P & $\begin{array}{l}\text { Extinguished } \\
\text { Flames }\end{array}$ & $\mathrm{N}$ \\
\hline Pine S.P. Biochar & $4.3 \%$ & N & P & $\begin{array}{l}\text { Extinguished } \\
\text { Flames }\end{array}$ & N \\
\hline $\begin{array}{c}\text { Red Oak F.P. Biochar } \\
450 C\end{array}$ & $2.6 \%$ & $\mathrm{~N}$ & P & & N \\
\hline $\begin{array}{l}\text { Red Oak F.P. Biochar } \\
500 C\end{array}$ & $3.7 \%$ & N & P & & N \\
\hline $\begin{array}{c}\text { Red Oak F.P. Biochar } \\
500 C \text { (II) }\end{array}$ & $3.4 \%$ & N & N & & N \\
\hline $\begin{array}{c}\text { Struemph } \\
\text { Commercial Charcoal }\end{array}$ & $2.3 \%$ & N & P & & N \\
\hline $\begin{array}{l}\text { Switchgrass } \\
\text { Gasification Char }\end{array}$ & N/A & N & P & & N \\
\hline $\begin{array}{l}\text { Switchgrass } \\
\text { Gasification Char }\end{array}$ & $1.3 \%$ & N & P & & N \\
\hline $\begin{array}{l}\text { Switchgrass Mini } \\
\text { Stove Char }\end{array}$ & $5.5 \%$ & N & P & & N \\
\hline
\end{tabular}

\begin{tabular}{|c|c|c|c|}
\hline \multicolumn{3}{|c|}{ Dried } & \\
\hline \multicolumn{3}{|c|}{ Method A } & Method B \\
\hline $\begin{array}{c}\text { Above } \\
\text { (3s) }\end{array}$ & $\begin{array}{c}\text { Contact } \\
(10 \mathrm{~s})\end{array}$ & Notes & 3 strikes \\
\hline N & p & & N \\
\hline N & P & $\begin{array}{c}\text { Extinguished } \\
\text { Flames }\end{array}$ & N \\
\hline N & p & & N \\
\hline N & N & & N \\
\hline N & $\mathrm{N}$ & & N \\
\hline N & N & & N \\
\hline N & P & & N \\
\hline N & P & $\begin{array}{c}\text { Extinguished } \\
\text { Flames }\end{array}$ & N \\
\hline N & p & & N \\
\hline N & P & & N \\
\hline N & P & $\begin{array}{c}\text { Extinguished } \\
\text { Flames }\end{array}$ & N \\
\hline N & p & & N \\
\hline N & p & & N \\
\hline N & N & & N \\
\hline N & P & & N \\
\hline N & P & & N \\
\hline N & p & & N \\
\hline N & P & & N \\
\hline N & p & $\begin{array}{c}\text { Extinguished } \\
\text { Flames }\end{array}$ & ' \\
\hline
\end{tabular}

Note: $\mathrm{P}=$ Positive, $\mathrm{N}=$ Negative. Samples under Method A Contact test for 10 seconds were deemed to give a positive result if flames were visible or embers remained for 20 seconds. 
Section 2 test method A - direct flame contact - resulted in several positive flammability results. All 10 biomass samples were positive. From the different biomasses tested, approximately half of them sustained flame, and the flames were well-visible and welldeveloped (corn cobs, corn stover, poplar sawdust, loblolly pine and switchgrass). Thirteen biochars were analyzed and only two produced negative results. The biochars did not produce an open flame but rather created embers that would remain partly lit for at least 20 seconds after the flame was removed. Four biochars required extinguishing the embers after 20 seconds. All the different biochar types studied here (gasification, slow pyrolysis, and fast pyrolysis biochar) did not show different responses among them. Three fossil fuels and derivatives were tested for comparison, and only coal produced a positive flammability result with embers lasting for more than 20 seconds.

Testing for flammability associated with vapor released (method B) indicated nonflammable for all the samples, mainly since these samples are solid and usually do not contain significant levels of adsorbed volatile compounds that could be released at room temperature or with a brief exposure to heat.

Analysis conducted after the materials were dried in the oven demonstrated comparable results to non-dried samples (as received). The biomass samples produced the same results, before and after drying; the vapor analysis was negative while the direct flame analysis was positive. Although some variation existed between the different carbonaceous materials, biochar samples had mostly similar responses. Only two samples that did not have a positive flammability result with the original moisture had a positive result after they were dried (red oak fast pyrolysis $500^{\circ} \mathrm{C}$ (II) and corn stover fast pyrolysis $500^{\circ} \mathrm{C}$ ).

Overall, the removal of the moisture led to no changes in the assessment of flammability, likely due to the fact that the moisture content of the materials "as received" was fairly dry (less than 10\% w.b.).

Table 8. ASTM D4982-95 Flammability Potentials Section A (vapor assessment immediately above and direct flames) different moisture levels of four fast pyrolysis biochars produced at $\sim 500^{\circ} \mathrm{C}$ in a fluidized bed reactor

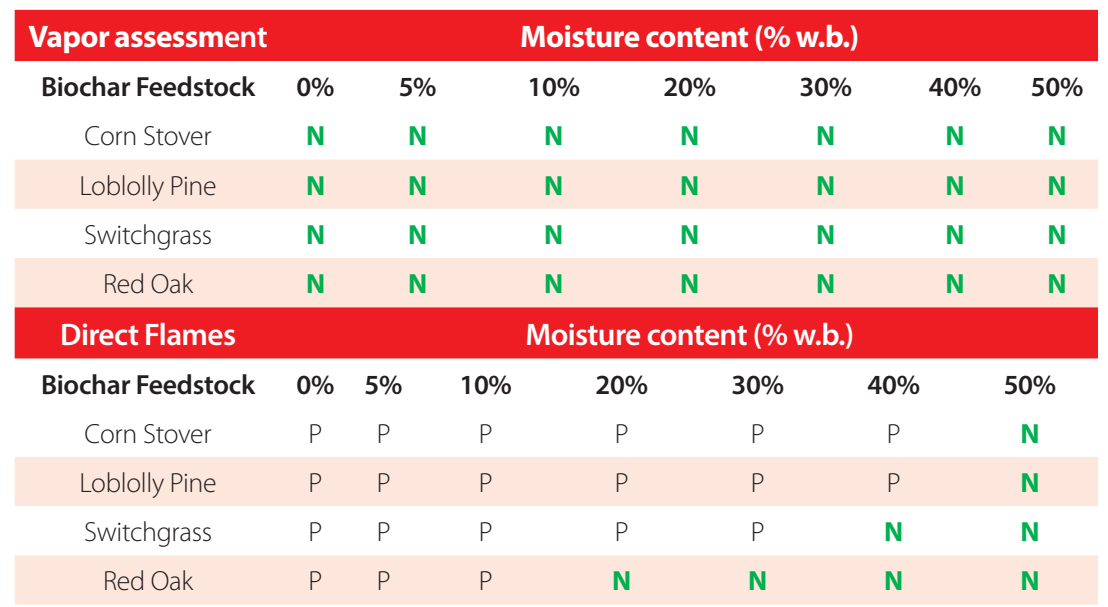

Note: $\mathrm{N}=$ Negative, $\mathrm{P}=$ Positive or when embers stay lit for at least 20 seconds 
Four fast pyrolysis biochars produced with different feedstocks (corn stover, loblolly pine, switchgrass and red oak) and pyrolyzed in a fluidized bed reactor at $\sim 500^{\circ} \mathrm{C}$ were used to evaluate the flammability potential with different moisture contents (Table 8). The vapor assessment was negative, similar to the previous results. The flammability response to the direct flame assessment was quite different among the four feedstocks. Red oak was least flammable; however, $20 \%$ of moisture content suppressed any flammability potential. Switchgrass required $40 \%$ moisture content to gain the same level of safety, while corn stover and loblolly pine required 50\% moisture to suppress flammability potential.

Overall, the four biochars with the addition of 20-50\% moisture by weight suppressed the flammability potential when measured according to ASTM D4982. Increasing moisture content is a simple method that can be used to ensure safer transportation and storage and can be used to further enhance safety in processing or storage facilities.

Overall, the biochar feedstocks tested with ASTM D4982 were "more flammable" than their corresponding biochar (with the same feedstock). Feedstocks had clearly welldeveloped flames that resulted in full consumption of the sample if not extinguished after the test. Most biochars, however, had embers that lasted for more than 20 seconds but over time went out and did not require extinguishing.

\section{CONCLUSIONS}

The fast pyrolysis biochars tested in this study are not considered flammable solid material under UN/DOT regulations for the transportation of dangerous goods. However, in reference to other studies, this material can self-heat and therefore needs to be further evaluated.

Tests to assess flammability, such as EPA 1030 or UN/DOT 1050 section A, demonstrated that fast pyrolysis biochar should be considered "not flammable" with respect to its flame propagation properties. Assessment according to ASTM D4982 showed that fast pyrolysis biochars from red oak, corn stover, loblolly pine, and switchgrass could be considered "flammable." It is important to note that this test can be subjective as the operator must visually determine whether the material is lit or not, which is characterized by fading embers. This subjectivity is a concern when testing this kind of material. However, addition of moisture to the biochar to 20 to 50\% w.b. completely suppressed the flammability potential when tested according to ASTM D4982.

Standards need to be developed to specifically address biochar safety as different methods may produce different outcomes, and some of these methods are subjective. Alternatively, standardized conditions need to be more precisely specified.

Fast pyrolysis biochars have a wide range of chemical properties due to the various types of feedstocks, the types of reactors, and the operating conditions. Therefore, it is essential to continue to test the different fast pyrolysis biochars until there is better understanding of the flammability characteristics and the conditions to avoid. Other biochar types (slow pyrolysis, gasification, and hydrothermal liquefaction chars) may 
have different flammability characteristics and should be tested until it is understood how the thermochemical process affects the flammability characteristics.

\section{ACKNOWLEDGEMENTS}

We acknowledge the financial support of lowa State University, Karl Goldsmith and Gabriel Buitrille for their diligent work and assistance on the data collection, as well as Dr. Robert Brown of lowa State University for his continuous support and mentoring.

\section{AUTHORS' CONTRIBUTIONS}

Bernardo del Campo conceived the investigation, developed the methodology and also made the acquisition, analysis and interpretation of data including field, laboratory and experimental. Thomas Brumm was the project administrator and also with Nir Keren they worked on the supervision and tutoring of the whole project. Bernardo del Campo wrote the manuscript, and Thomas Brumm and Nir Keren reviewed critically the intellectual content of the manuscript. Finally, Bernardo del Campo took photographs and results.

\section{CONFLICT OF INTEREST}

The author declares that the data gathering and research were performed in the absence of any commercial or financial relationships that could be construed as a potential conflict of interest. The author currently works in a company that produces biochar and biochar equipment. 


\section{? REFERENCES}

[1] International Biochar Initiative, (2012). Standardized product definition and product testing guidelines for biochar that is used in soil. IBI biochar standards. Recovered from http://www.biochar-international.org/sites/default/files/ Guidelines_for_Biochar_That_Is_Used_in_Soil_Final.pdf

[2] Lehmann, J., \& Joseph, S. (Eds.). (2015). Biochar for environmental management: science, technology and implementation. Routledge. doi: https://doi.org/10.1002/bbb.169

[3] Laird, D. A., Brown, R. C., Amonette, J. E., \& Lehmann, J. (2009). Review of the pyrolysis platform for coproducing bio-oil and biochar. Biofuels, bioproducts and biorefining, 3(5), 547-562. doi: https://doi.org/10.1002/bbb.169

[4] Lehmann, J., Gaunt, J., \& Rondon, M. (2006). Bio-char sequestration in terrestrial ecosystems-a review. Mitigation and adaptation strategies for global change, 11(2), 403-427. doi: https://doi.org/10.1007/s11027-005-9006-5

[5] Jeffery, S., Verheijen, F. G., van der Velde, M., \& Bastos, A. C. (2011). A quantitative review of the effects of biochar application to soils on crop productivity using meta-analysis. Agriculture, ecosystems \& environment, 144(1), 175187. doi: https://doi.org/10.1016/j.agee.2011.08.015

[6] Boateng, A. A., Garcia-Perez, M., Mašek, 0., Brown, R., \& del Campo, B. (2015). Biochar production technology. In Biochar for environmental management (pp. 95-120). Routledge. doi: https://doi.org/10.4155/cmt.10.32

[7] Spokas, K. A. (2010). Review of the stability of biochar in soils: predictability of 0: C molar ratios. Carbon Management, 1(2), 289-303.

[8] Mukome, F. N., \& Parikh, S. J. (2015). Chemical, physical, and surface characterization of biochar (pp. 68). CRC Press, Boca Raton, FL.

[9] del-Campo, B. G., Morris, M. D., Laird, D. A., Kieffer, M.M., \& Brown, R.C. (2015). Optimizing the production of activated carbon from fast pyrolysis char. Technology, 3(02n03), 104-113. doi: https://doi.org/10.1142/\$2339547815400026

[10] Hawtin, P., Lewis, J. B., Moul, N., \& Phillips, R. H. (1966). The heats of combustion of graphite, diamond and some non-graphitic carbons. Philosophical Transactions of the Royal Society of London. Series A, Mathematical and Physical Sciences, 261(1116), 67-95. doi: https://doi.org/10.1098/rsta.1966.0058

[11] Zhao, M. Y., Enders, A., \& Lehmann, J. (2014). Short-and long-term flammability of biochars. biomass and bioenergy, 69, 183-191. doi: https://doi.org/10.1016/j.biombioe.2014.07.017

[12] Code of Federal Regulations, Title 49 FR Parts 100-199 (Transportation). Superintendent of Documents, US Government Printing Office, Washington, DC, 20402.

[13] United Nations. Committee of Experts on the Transport of Dangerous Goods. Recommendations on the Transport of Dangerous Goods: Manual of tests and criteria (Vol. 11). United Nations Publications, 2009.

[14] Joseph, G., \& Team, C. H. I. (2007). Combustible dusts: A serious industrial hazard. Journal of hazardous materials, 142(3), 589-591. doi: https://doi.org/10.1016/j.jhazmat.2006.06.127

[15] Cote, Arthur E. Fire protection Handbook. National Fire Protection Association, $19^{\text {th }}$ edition volume I, 2002.

[16] Brown, T. R., Wright, M. M., \& Brown,. C. (2011). Estimating profitability of two biochar production scenarios: slow pyrolysis vs fast pyrolysis. Biofuels, Bioproducts and Biorefining, 5(1), 54-68. doi: https://doi.org/10.1002/bbb.254

[17] U.S. Environmental Protection Agency. "Test Method for the Evaluation of Solid Wastes"-Physical and Chemical Methods, Method 1030, Ignitability of Solids,"U.S. EPA Washington Solid Waste Website: https://www.epa.gov/hwsw846/sw-846-test-method-1030-ignitability-solids

[18] American Society for Testing and Materials, ASTM D4982-07 Standard Test Method for Flammability Potential Screening Analysis of Waste, 2007.

[19] Brown, T. R., \& Brown, R. C. (2013). Biorenewable resources: engineering new products from agriculture. John Wiley \& Sons. 
Artículo/Article

[20] FAO Simple Technologies for Charcoal Making, Second Printing, FAO Forestry Paper 41, Food and Agriculture Organization of the United Nations, Rome, 1987. Available at www.fao.org/docrep/S5328e/x5328e00.htm, accessed June 2015

[21] del Campo, B. G. (2015). Production of activated carbon from fast pyrolysis biochar and the detoxification of pyrolytic sugars for ethanol fermentation. 